\title{
14 Effect of Low-Power Laser Biotechnology Pretreatment on Shooting and Initial Growth of White Mulberry and Sugarcane under Flood Stress
}

Sergio Rodríguez Rodríguez

University of Granma

Eduardo Ortega Delgado

University of Havana

Juan José Silva Pupo

University of Granma

Alexander Álvarez Fonseca

Research Agricultural Institute "Jorge Dimitrov"

Medardo Ángel Ulloa Enríquez

Technical University of Cotopaxi

Luis Enrique Arias Basulto

University of Granma

\section{CONTENTS}

Introduction.

Effects of Low-Power Laser Biotechnology Pretreatment on the Shooting and

Initial Growth of Mulberry and Sugarcane

Materials and Methods

Results and Discussion

Effects of Low-Power Laser Biotechnology Pretreatment under Flooding Stress in

Mulberry and Sugarcane

Materials and Methods

Results and Discussion

References. 


\section{INTRODUCTION}

The problem of soil flooding is global and affects crop yields on all the continents of our planet (Peratae et al., 2011), and it is estimated that 6\% of terrestrial land is waterlogged or prone to temporary flooding, due to heavy rainfall and poor soil drainage (De la Cruz et al., 2012; Maltby, 1991). In Latin America, waterlogging affects $11.3 \%$ of the cultivated land, while in Cuba, poor drainage affects up to $40.3 \%$ of the cultivated agricultural area (CIGEA, 2001).

The term flooding encompasses both excess water accumulation in the soil and submersion. The accumulation of water can involve soil flooding, where only the roots are exposed to these conditions, and immersion, when the plant is partially or fully submerged (Sasidharan and Voesenek, 2015). Flood events have become more frequent, severe and unpredictable and are strongly associated with climate change.

The gas exchanges in the organs of flooded plants lead to the restriction of two vital plant processes, photosynthesis and respiration, which can be attributed to water being an extremely poor medium for the diffusion of gases, mainly oxygen. Most terrestrial plants, including major crops, are extremely sensitive to wet conditions. The adaptation of a plant to flooding includes molecular, physiological, morphological and anatomical changes. Initiating these changes requires an accurate and timely perception by the plant of excess water in order to invoke adaptive responses in the early stages of vegetative growth (Sasidharan and Voesenek, 2015).

In industrial farming, different chemical additives are used to raise the productivity of plants and livestock. Their application can cause the contamination of raw materials for food production with toxins that are dangerous for consumers' health as well the environment. On-farm safety for fresh produce requires the development and implementation of new methods for quality assurance. Through the substitution of chemical ameliorations by physical methods, one can reduce the toxins in the raw materials and thus raise the food safety levels and mitigate environmental concerns (Aladjadjiyan, 2007; Aladjadjiyan and Kakanakova, 2008; Jacubiak and Gdowska, 2013).

Thus, the treatment of seeds from agricultural crops by non-polluting substances and techniques could bring both qualitative and quantitative increases in agricultural production: a possibility that has led to increased interest in applying biophysical techniques in agriculture (Hernández et al., 2010; Mosneaga et al., 2018; Vasilevski, 2003).

Among the biophysical methods used for seed priming are treatments involving magnetic fields (De Souza and Garci, 1999; De Souza et al., 2006), temperature or thermo-priming (Paparella et al., 2015); light amplification by stimulated emissions of radiation or laser (Álvarez et al., 2011); X-rays (Ramírezet al., 2006); ultrasound (Yaldagard et al., 2008); gamma and beta radiation (Mirshekari, 2015); the use of plasma (Volin et al., 2000); and microwave radiation (Banik et al., 2003). All are potential alternatives to reducing the synthetic additives and fertilisers applied to the soil and plants.

Laser treatment involves emitting monochromatic coherent light waves in a controlled fashion (Aladjadjiyan, 2007). The literature concludes that it can be considered a safe technique, as it does not alter the molecular bonds, has no mutagenic effect and does not cause marked morphological changes in the structure of the tissue (Mosneaga et al., 2018). Laser biotechnology has a wide range of applications; it can be used in sustainable environmental engineering and preventive biotechnology to eliminate heavy metal contamination on degraded land, as well as in wastewater treatment bioremediation (Dobrowolski, 2010; Dobrowolski et al., 2012a,b; Mosneaga et al., 2018).

There are many studies about low-power laser biostimulation treatment, applied to plants to stimulate germination, shooting, rooting and plant growth. These include the following:

- improved growth and yield by stimulating morphological change (Hernández et al., 2016; Ivanova, 1998; Perveen et al., 2011; Podlesny and Podlesna, 2004; Podlesny et al., 2012; Ying and Chen, 2010);

- stimulating germination (Abu-Elsaoud, 2013; Hoseini et al., 2013; Jamil et al., 2013; Muthusamy et al., 2012; Podlesna et al., 2015); 
- seedling growth (Mosneaga et al., 2018);

- stimulation of cell proliferation through photostimulatory effects in mitochondria $(\mathrm{Hu}$ et al., 2007);

- protection against UV-B radiation damage (Abu-Elsaoud and Shahda, 2017; Al-Zhen et al., 2012; Chen and Han, 2014, 2015; Jia and Duan, 2013; Yang et al., 2012);

- stimulated leaf area and parameters of photosynthetic activity (Rybinski and Garczynski, 2004);

- increased nuclease activity of the leaves and roots (Zhang and Han, 2009);

- increased ATP level in cells cultivated under in vitro conditions (Karu et al., 1995); and

- improvements in the chemical composition and structure of lipids in tissue culture (Salyaev et al., 2007).

Laser treatment has been used to increase tolerance to various types of stress, such as the following:

- drought stress (Wu et al., 2007; Metwally et al., 2014; Qiu et al., 2008a,b; Qiu et al., 2017);

- increased drought stress resistance for repairing damage to plants exposed to osmotic stress (Qiu et al., 2008c, 2010) and membrane lipid peroxidation (Wu et al., 2007);

- low temperatures (Chen et al., 2010);

- salinity stress (Ashrafijou et al., 2010; Duan et al., 2010; Gao et al., 2014; Mohammadi et al., 2012; Rasouli et al., 2012; Zare et al., 2014); and

- changes in oxidative stress in response to antioxidant defence (Abu-Elsaoud, 2013; Abu-Elsaoud and Tuleukhanov, 2013; Chen, 2009; Qiu et al., 2013).

In the international scientific literature, most laser treatment research has been conducted with botanical seeds, and less with plant cuttings (Bąbelewski and Szajsner, 2014; Jakubiak and Gdowska, 2013; Rimal et al., 2014; Szajsner and Bąbelewski, 2014).

Plant growth regulators, as well as exogenous plant hormones (bioregulators), are known to be able to increase their tolerance to excess water in the environment. This has been encouraged with the use of paclobutrazol (Lin et al., 2006), putrescine (Yui et al., 2009a), spermine (Yiu et al., 2009b) and ethylene (Wang et al., 2016). Specific attention is drawn to the use of the bioregulator 5-aminolevulinic acid (ALA) in stress pretreatments, as it regulates several key physiological processes; for example, it significantly improves the waterlogging tolerance of fig (Ficus carica) and promotes root breathing, leaf photosynthesis and antioxidant capacity (An et al., 2016).

Mulberry (Morus alba) and sugarcane (Saccharum spp.) are two important species of plants grown commercially in Cuba; the former is increasingly used as a fodder crop and the latter is the main commercial crop for sugar production, but has multiple other uses, such as animal feed and derivatives. Commercially, both crops are propagated by stakes to ensure varietal homogeneity, but varietal characteristics, management factors and environmental conditions may result in low shooting rates and poor early-stage growth that affects crop yields.

The objective of this research was to determine the effect of low-power laser biotechnology pretreatment on the shooting and initial growth of mulberry and sugarcane under normal irrigation conditions and under flood stress.

\section{EFFECTS OF LOW-POWER LASER BIOTECHNOLOGY PRETREATMENT ON THE SHOOTING AND INITIAL GROWTH OF MULBERRY AND SUGARCANE}

\section{Materials and Methods}

Ninety 1-bud sets of the Acorazonada variety were cut from the mulberry seed bank (Morus alba) of the Plant Biotechnology Study Center, University of Granma, Cuba, along with 90 one-bud sets from 10-month-old sugarcane (variety C90-469) and their stalks from the sugarcane seed bank of 
the sugar company 'Archimedes Colina', Mabay, Bayamo, Granma, Cuba (using the methodology of the National Institute of Sugarcane Research) (INICA, 2002).

Sixty stalk segments of one-bud sets of each crop were irradiated with laser beams using medical laser or He-Ne, wavelength $660 \mathrm{~nm}$, red light power density of $360 \mathrm{~mW} . \mathrm{cm}^{-2}$. The laser treatments consisted of two irradiation times to the buds: 10 seconds (30 one-bud sets) and 20 seconds (30 one-bud sets), with a control treatment consisting of 30 one-bud sets that did not receive laser treatment. The buds were placed in nylon containers that are commonly used to market milk or yogurt in Cuba, with a substrate consisting of 50\% soil and 50\% cow manure. The percentage of vegetative bud break in each species was determined after 15 and 30 days.

In both crops, the variable was checked to see whether it met the criteria for a variance analysis, the normal distribution of data through the Shapiro-Wilk test, using InfoStat 2019 (Di Rienzo et al., 2019), and the homogeneity of variances using the Levene test (Minitab, 2013). The data were found to be distributed normally, and their variances were homogeneous. The data were statistically processed through a fixed-effect simple-classification variance analysis, with a two-factor treatment of $2 \times 2$. Factor 1 corresponded to the laser-beam treatment with two exposure times: 10 and $20 \mathrm{sec}-$ onds; and factor 2 corresponded to the two different times when the evaluations were performed: 15 and 30 days. The multiple comparisons of the mean treatments were made using Tukey's test at $5.0 \%$ probability. The mean of each treatment and its standard error were represented in a bar chart (see Figure 14.1).

\section{Results and Discussion}

A significant response to the laser applications was found for vegetative bud breaks in mulberry. The best response was found to the laser applications lasting 10 seconds, with $76.7 \%$ of vegetative bud break, compared to $63.3 \%$ with a laser application lasting 20 seconds, and $60.6 \%$ bud break (Figure 14.1a) in the control treatment (with no laser application). No significant differences were found between the two time intervals evaluated (Figure 14.1b), indicating that during this period there were no morphological qualitative changes in the development of new mulberry shoots through the effect of laser beams (Figure14.1).

When the percentages of vegetative bud breaks for the two laser exposure time periods were combined and compared to the control, significant differences in the interactions between these two treatments were found (Figure 14.1c). The higher percentages of budding occurred in buds that received laser treatments for a space of 10 seconds, percentages that increased as the days passed. The lowest percentages were obtained in the control at 15 days, with an increase at 30 days, while with 20 seconds of laser exposure, intermediate results were achieved in both evaluations (after 15 and 30 days)

The same procedure was repeated on the sugarcane (variety C90-469), and produced similar results to the mulberry (Figure 14.2). The highest percentage of vegetative bud break, at $85.6 \%$, was with the application of the laser for 10 seconds, followed by the control treatment with $64.4 \%$, while the lowest bud break was the application of the laser for 20 seconds, with 58.9\% (although there was no significant difference between the latter two). As with the mulberry experiment, no significant time factor effects were found.

\section{EFFECTS OF LOW-POWER LASER BIOTECHNOLOGY PRETREATMENT UNDER FLOODING STRESS IN MULBERRY AND SUGARCANE}

\section{Materials and Methods}

For this experiment, plants from the laser treatment that resulted in the best bud break - exposure for 10 seconds and after 30 days- were used, together with a control. Forty cuttings were prepared (20 of mulberry cuttings and 20 of sugarcane) from the first experiment that were exposed to 
(a)

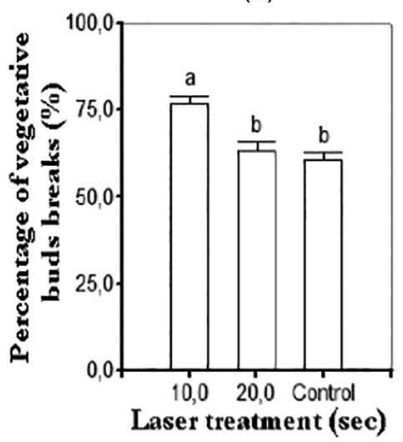

(b)

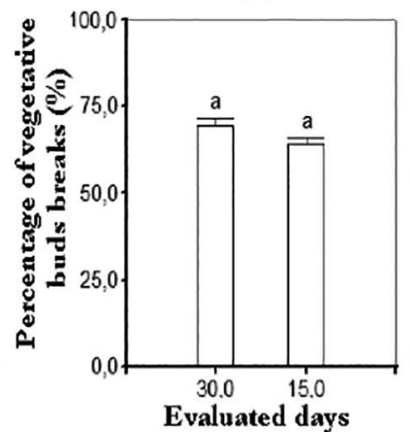

(c)

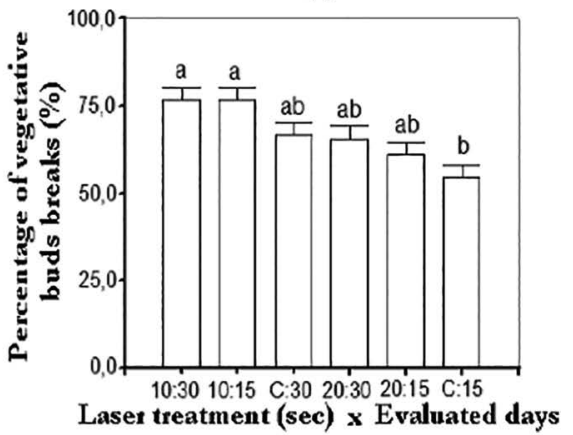

FIGURE 14.1 Percentage of vegetative bud breaks in mulberry, variety Acorazonada, produced by the effect of two laser treatments (10 and 20 seconds) plus the control (graph a), assessed at 15 and 30 days from the initiation of treatments (graph b), and the combination of the two (graph c). Different letters indicate significant differences at $p<0.05$ using Tukey's test.

(a)

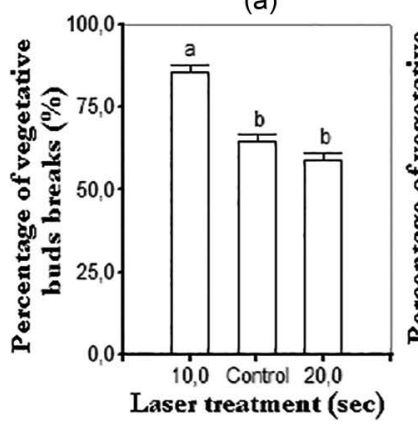

(b)

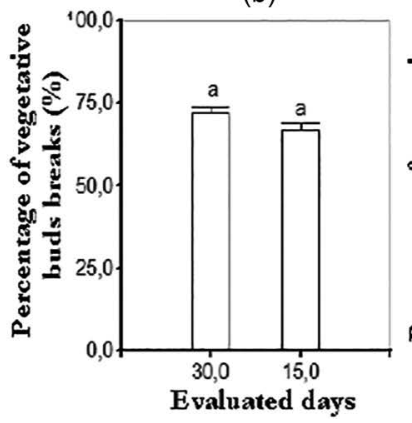

(c)

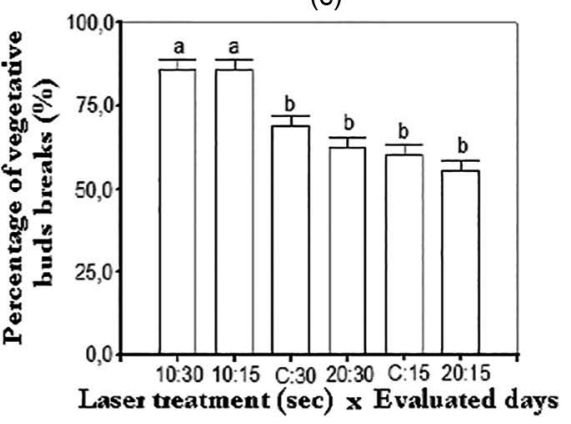

FIGURE 14.2 Percentage of vegetative bud break in sugarcane, variety C90-469, produced by the effect of two laser treatments (10 and 20 seconds) plus the control (graph a), assessed at 15 and 30 days from the initiation of treatments (graph b), and the combination of the two (graph c). Different letters indicate significant differences at $p<0.05$ using Tukey's test.

this most favourable treatment. Thirty-five days after the treatment, the bud bags (20 stakes with their shoots) were immersed in a pond to a water level that did not completely cover the shoots. They were kept there for 3 days and then held for 4 days out of the water. This weekly process was repeated for 4 weeks (replicating flooding conditions).The remaining 20 cuttings of each crop were applied with water every 3 days (without excess, replicating non-flood conditions). A control treatment was established for both crops at the same age, without the application of laser and without stress due to excess water. At the end of 4 weeks or 63 days in total if counting from the start of the first experiment, the length of the shoots (in $\mathrm{cm}$ ) and the area of the aerenchyma ${ }^{1}\left(\right.$ in $\left.\mu \mathrm{m}^{2}\right)$ were assessed.

For the histological study, samples of first-order branched roots of each crop (which were physiologically active, characterised by light coloration, absence of necrosis and suberisation) of an average diameter of $2 \mathrm{~mm}$ and a total length of $5 \mathrm{~cm}$ were collected. Three replicates were selected

\footnotetext{
${ }^{1}$ Aerenchyma is spongy tissue that forms spaces or air channels in the leaves, stems and roots of some plants, which allows exchange of gases between the shoot and the root. There are two types: lysigenous and schizogenous.
} 
from each variety and ten root samples were taken from each replicate. Histological sampling was performed in the area between 1.0 and $1.5 \mathrm{~cm}$ from the apex of the root upwards.

The root samples were kept in liquid nitrogen until they were taken to the lab. From there, crosssections of $0.2 \mathrm{~mm}$ thickness were made and analysed under an optical microscope. Digital photos were taken, and the aerenchyma tissue area was calculated using the Motic Images Plus 2.0 program (Motic Instruments Inc., Richmond, Canada) through morphometric methods that gave a magnification of up to $400 \times$.

Prior to the analysis of variance of variations in vegetative bud break in this experiment, it was checked whether the variable met the premises of the analysis of variance, the normal distribution of the data through the Shapiro-Wilk test (Di Rienzo et al., 2019) and the homogeneity of variances using the multiple comparison test (Minitab, 2013). The data were statistically processed through a fixed-effect simple-classification variance analysis, with three treatments for both crops, cuttings with their shoots that received lasers for 10 seconds and a life cycle of 30 days in non-flooding conditions (10`30d NF) and in flooding conditions (10`30d F) and one treatment control (laser-free and stress-free). As the data collected did not follow a normal distribution, the variance analysis of nonparametric form was by the Kruskal-Wallis test. The comparison of treatments was made through the range means (Conover, 1999). For each treatment, the mean of means and their standard error were determined.

\section{Results and Discussion}

Table 14.1 shows the differences in leaf shoot length in mulberry, which was significant between the three treatments in general. However, the use of the laser in conditions of stress due to over-wetting was not significantly different from the laser treatment in normal conditions of humidity of the substrate, which suggests that regardless of whether there is excess water, the influence of the laser stimulates the growth of the leaf shoots. The length of the shoot in the control treatment (without the application of laser) was significantly lower than that reached in the treatments where the laser was applied.

For aerenchyma tissue, the three treatments showed significantly different results: a greater growth of this tissue was found on samples that were treated with the laser and placed in conditions of excess water in the substrate, significantly more than those subject to the laser treatment but not to excess water. The lowest growth of the aerenchyma was in the control treatment (in which the laser treatment was not applied and the moisture conditions of the substrate were normal).

Similar results were found when evaluating sugarcane shoots, variety C90-469 (Table 14.2). Both results show that the physical effect of laser beams triggers biochemical and physiological

TABLE 14.1

Mean Values of Foliar Bud Length (cm) and Root Aerenchyma Area (in $\mu \mathrm{m}^{2}$ ) in Mulberry Seedlings, Acorazonada Variety, Treated with Laser for 10 Seconds and Evaluated under Flood (F) and Non-Flooded Stress (NF) in the Substrate, and the Control (No Laser Treatment and No Excess Moisture)

Leaf Shoot Length (Mulberry)

\begin{tabular}{lc}
\hline Treatments & Average \pm SD \\
$10 ` 30 \mathrm{~d} \mathrm{NF}$ & $16.09 \pm 0.70$ \\
$10^{\prime} 30 \mathrm{~d} \mathrm{~F}$ & $15.86 \pm 0.45$ \\
Control & $14.03 \pm 0.97$
\end{tabular}

Aerenchyma Area (Mulberry)

\begin{tabular}{ccc}
\hline Ranges & Average \pm SD & Ranges \\
$41.40^{\mathrm{a}}$ & $10739122.9 \pm 3056151$ & $30.5^{\mathrm{b}}$ \\
$37.38^{\mathrm{a}}$ & $30182546.9 \pm 2714263$ & $50.5^{\mathrm{a}}$ \\
$12.73^{\mathrm{b}}$ & $186826.1 \pm 120669,9$ & $10.5^{\mathrm{c}}$
\end{tabular}

Different letters indicate significant differences at $p<0.05$ through the differences between the averages of the ranges. 
TABLE 14.2

Mean Values of Foliar Shoot Length (cm) and Root Aerenchyma Area (in $\mu \mathrm{m}^{2}$ ) in Sugarcane Seedlings, Variety C90-469, Treated with Laser for 10 Seconds and Evaluated under Flood (F) and Non-Flooded Stress (NF) in the Substrate, and the Control (No Laser Treatment and No Excess Moisture)

Leaf Shoot Length (Sugarcane)

\begin{tabular}{lc}
\hline Treatments & Average \pm SD \\
$10^{\prime 30 d ~ N F ~ F ~}$ & $96.08 \pm 5.59$ \\
$10 ` 30 d$ F & $96.23 \pm 5.88$ \\
Control & $91.51 \pm 4.64$
\end{tabular}

\begin{tabular}{ccc}
\multicolumn{3}{c}{ Aerenchyma Area (Sugarcane) } \\
\hline Ranges & Average \pm SD & Ranges \\
$35.15^{\mathrm{a}}$ & $6437131 \pm 2010409$ & $30.5^{\mathrm{b}}$ \\
$35.25^{\mathrm{a}}$ & $18046968.8 \pm 1406608.9$ & $50.5^{\mathrm{a}}$ \\
$21.10^{\mathrm{b}}$ & $108691 \pm 72487.7$ & $10.5^{\mathrm{c}}$
\end{tabular}

Different letters indicate significant differences at $p<0.05$ through the differences between the averages of the ranges.

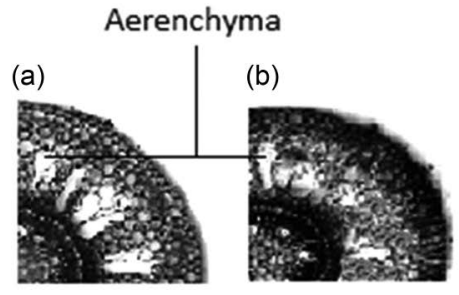

Mulberry

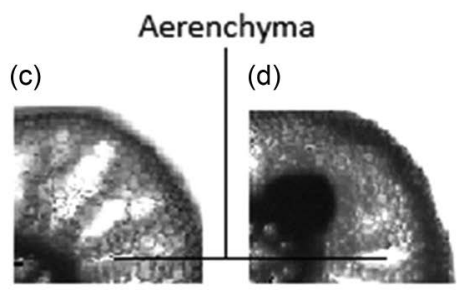

Sugarcane

FIGURE 14.3 Histological cross section. (a) Mulberry root, Acorazonada variety, with laser application for 10 seconds in conditions of excess water; (b) mulberry root, Acorazonada variety, with no application of laser rays in conditions of excess water; (c) sugarcane root, variety C90-469, with laser application for 10 seconds in conditions of excess water; and (d) sugarcane root, variety C90-469, with no application of laser rays in conditions of excess water.

mechanisms that produce greater elongation of the main mulberry and sugarcane shoots in a substrate with oxygen restriction, indicating that pretreating the buds of these crops has a robust effect, which allows them a normal early-stage growth and better subsequent development under stress conditions with an oxygen deficit.

The laser-stimulating effect on the leaf shoot length under the effect of oxygen deficiency in relation to the control may be associated with a greater development of the aerenchyma tissue (Tables 14.1 and 14.2 and Figure 14.3) at the roots of mulberry and the sugarcane shoots, which accentuated the formation of aerenchymatic tissue in the substrate with water excess. This suggests that the laser stimulates the synthesis of the ethylene hormone, which under these conditions is responsible for the formation of this tissue by apoptosis or cell death of the genetically programmed parenchymal cells. This in turn promotes the formation of porous spaces or ducts from the roots to the aerial parts of the plant and facilitates the entry of oxygen from the surrounding atmosphere to the roots. As such, it constitutes an important adaptation of certain plant species to live and develop in soils with excess water.

Although ethylene has an inhibitory effect on stem growth for most plant species, it has been found that certain plant species are tolerant of oxygen deficits in the soil. This plant hormone can act as a stimulator of stalk growth due to an increase in the synthesis of the precursor of ethylene, 1-aminocyclopropane-1-carboxylic acid (ACC), under hypoxia conditions (Jackson, 2007; Voesenek et al., 1992; Voesenek et al., 1993), which causes a decrease in the levels of the phytohormone 
abscisic acid (ABA) and an increase in the phytohormone gibberellic acid (GA; Azcón-Bieto and Talon, 2008; Voesenek and Van Deer Veen, 1994).

It is important to look at other morphological adaptations. The C90-469 sugarcane variety showed inverse correlations between stoma density and stoma length in the stimulated flood conditions (Rodríguez et al., 2017). In the gas exchange between the plant and the environment, there is a connection between stomata and aerenchyma tissue.

\section{CONCLUSIONS}

The growing world population is constantly putting pressure on the need to increase food production, which in turn is affected by the edaphoclimatic phenomena (the influence of soils on plants in relation to climate), such as the frequent extreme events of high and low temperatures, droughts and floods and hurricanes. Flooding is a natural disaster that affects both humans and plants, and man-made driving factors of flooding include deforestation, and intensive agriculture characterised by extensive use of machinery and chemical products, which contaminate water sources, plants, animals and humans as well as being one of the causes of the increase in greenhouse gases that exacerbates climate change due to the increase in the annual average temperature. Agroecological production of food offers a balanced and sustainable alternative, and one more sustainable tool is preconditioning seeds and buds with physical methods. The use of lasers to precondition plant buds such as mulberry and sugarcane in order to increase sprouting and initial growth seems to be a viable method. It has the effect of activation of biochemical, physiological and morphological factors that can increase the tolerance of plants to excess water in the soil, by increasing the aerenchymatic tissue at the root. This apparently stimulates the synthesis of the ethylene hormone within the plant that, under this type of stress, induces shoot growth. This research needs further development although we are confident that the use of low-power biotechnological laser may provide a useful technique for conditioning seeds and vegetative parts in stressful environments at an industrial scale.

\section{ACKNOWLEDGEMENTS}

This research is part of the project 'In vitro plant biotechnology to increase food security in eastern Cuba', TEAM2017PR438-75644, funded by the Vlaamse Interuniversitaire Raad (VLIR),between the Laboratory of Applied In-Vitro Plant Biotechnology, Department of Applied Biosciences Engineering, University of Ghent, Belgium, and Plant Biotechnology Study Center, Faculty of Agricultural Science, University of Granma, Cuba.

\section{REFERENCES}

Abu-Elsaoud, A. M. (2013) Double-pulse laser light treatment stimulate germination and changes the oxidative stress and antioxidant activities of wheat (Triticum aestivum). Journal of Ecology of Health and Environment 1:1-11.

Abu-Elsaoud, A. and Shahda, R. (2017) Role of the He-Ne laser pretreatment in protecting Zea mays against the deleterious effects of ultraviolet radiations. Egyptian Journal of Experimental Biology (Botany) 13:403-422.

Abu-Elsaoud, A. M. and Tuleukhanov, S. T. (2013) Can He-Ne laser induce changes in oxidative stress and antioxidant activities of wheat cultivars from Kazakhstan and Egypt? Science International 1:39-50.

Aladjadjiyan, A. (2007) The use of physical methods for plant growing stimulation in Bulgaria. Journal Central European Agriculture 8:369-380.

Aladjadjiyan, A. and Kakanakova, A. (2008) Physical methods in agro-food chain. Journal Central European Agriculture 9:789-794.

Álvarez, A., Ramírez, R., Chávez, L., Camejo, Y., Licea, L., Porras, E. and García, B. (2011) Efecto del tratamiento de semillas con láser de baja potencia, sobre el crecimiento y rendimiento en plantas de tomate (Solanum lycopersicum L.). ITEA 4:290-299 [In Spanish].

Al-Zhen, M. A., Su-Hua, L. I., Xiao-Li, W. E. I. and Rong, H. A. N. (2012) Effects of He-Ne laser and enhanced ultraviolet-B radiation on MAP65s of wheat seedlings. Journal of Biology 4:015. 
An, Y., Qi, L. and Wang, L. (2016) ALA pretreatment improves waterlogging tolerance of fig plants. PLoS One 11(1): $\mathrm{e} 0147202$.

Ashrafijou, A., Sadat Noori, S. A., Izadi Darbandi, A. and Saghafi, S. (2010) Effect of salinity and radiation on proline accumulation in seeds of canola (Brassica napus L.). Plant Soil Environment 56:312-317.

Azcón-Bieto, J. and Talon, M. (2008) Fundamentos de Fisiología Vegetal, Segunda Edición. Ed. Interamericana, MacGraw-Hill-Interamericana de España: Madrid, 651p, [In Spanish].

Bąbelewski, P. and Szajsner, H. (2014) Attemption of applying laser photostimulation to the rooting of shoot cuttings of juniper species. Acta Scientiarum Polonorum Hortorum Cultus 13:135-144.

Banik, S., Bandyopadhyay, S. and Ganguly, S. (2003) Bioeffects of microwave:A brief review. Bioresource Technology 87:155-159.

Chen, H. and Han, R. (2014). He-Ne laser treatment improves the photosynthetic efficiency of wheat exposed to enhanced UV-B radiation. Laser Physics 24:105602.

Chen, H. and Han, R. (2015) He-Ne laser influenced acting filaments alleviate the damage of UV-B in wheat. Laser Physics 25:5601.

Chen, Y. P. (2009) Response of antioxidant defense system to laser radiation on apical meristem of Isatis indigotica seedlings exposed to UV-B. Plant Signaling and Behavior 4:571-573.

Chen, Y. P., Jia, J. F. and Yue, M. (2010) Effect of $\mathrm{CO}_{2}$ laser radiation on physiological tolerance of wheat seedlings exposed to chilling stress. Photochemistry and Photobiology 86:600-605.

CIGEA (2001) Síntesis del Diagnóstico de la Desertificación y la Sequía en Cuba. Caracterización del archipiélago Cubano. Centro de Información, Gestión y Educación Ambiental: La Habana [In Spanish].

Conover, W. J. (1999) Practical Nonparametric Statistics. John Wiley and Sons, Inc.: New York.

De la Cruz, J., Moreno, P. and Magnitskiy, S. (2012) Respuesta de las plantas a estrés por inundación. Revista Colombiana de Ciencias Hortícolas 6:96-109 [In Spanish].

De Souza, A. and Garci, D. (1999) Efecto del tratamiento magnético de semillas de tomate (Lycopersicon esculentum Mill.) sobre la germinación y el crecimiento de las plántulas. Investigación Agronómica de Protección Vegetal 14:437-444 [In Spanish].

De Souza, A., Garci, D., Sueiro, L., Gilart, F., Porras, E. and Licea, L. (2006) Pre-sowing magnetic treatments of tomato seeds increase the growth and yield of plants. Bioelectromagnetics 27:247-257.

Di Rienzo, J. A., Casanoves, F., Balzarini, M. G., Gonzalez, L., Tablada, M. and Robledo, C. W. (2019) InfoStat versión 2019. Centro de Transferencia InfoStat, FCA, Universidad Nacional de Córdoba, Argentina. http://www.infostat.com.ar.

Dobrowolski, J. W. (2010) Laser biotechnology for more efficient bioremediation and sustainable development. Journal of Chemical Technology and Biotechnology 150:264-265.

Dobrowolski, J. W., Budak, A., Trojanowska, D., Rymarczyk, M. and Macuda, J. (2012a.) Laser stimulation of Trichophyton mentagrophytes for the enhancement biodegradation of hydrocarbons. Environmental Engineering and Management Journal 11:1783-1788.

Dobrowolski, J. W., Śliwka, M. and Mazur, R. (2012b) Laser biotechnology for more efficient bioremediation, protection of aquatic ecosystems and reclamation of contaminated areas. Journal of Chemical Technology and Biotechnology 87:1354-1359.

Duan, Z. Y., Yang, Z. F. and Yang, Z. R. (2010) Effects of He-Ne laser irradiation on salt tolerance of tomato seedlings. Acta Laser Biology Sinica 2:7.

Gao, L. M., Li, Y. F. and Han, R. (2014) He-Ne laser preillumination improves the resistance of tall fescue (Festuca arundinacea Schreb.) seedlings to high saline conditions. Protoplasma 1:1-14.

Hernández, A. C., Domínguez, P. A., Crúz, O. A., Ivanov, R., Carballo, C. A. and Zepeda, B. R. (2010) Laser in agriculture. International Agrophysics 24:407-422.

Hernández, A. C., Domínguez, P. A., Cruz, O. A., Podlesna, A., Ivanov, R., Carballo, C. A., Perez, R. M. C., Sanchez, H. G., Zepeda, B. R. and Lopez, B. J. L. (2016) Bioestimulación láser en semillas y plantas. Gayana Botanica 73:132-149 [In Spanish].

Hoseini, M., Feqenabi, F., Tajbakhsh, M. and Babazadeh-Igdir, H. (2013) Introduction of seed treatment techniques (seed priming). International Journal of Biosciences 3:1-12.

Hu, W. P., Wang, J. J., Yu, C. L., Lan, C. C. E., Chen, G. S. and Yu, H. S. (2007) Helium-neon laser irradiation stimulates cell proliferation through photostimulatory effects in mitochondria. Journal of Investigative Dermatology 127:2048-2057.

INICA (2002) Normas y Procedimientos del Programa de Mejoramiento Genético de la Caña de Azúcar en Cuba. Instituto Nacional de Investigaciones de la Caña de Azúcar. Boletín No. 1 Cuba and Caña INICA: La Habana, Cuba, 315 p [In Spanish].

Ivanova, R. (1998) Influence of pre-sowing laser irradiation of seeds of introduced flax varieties of linseed oil on yield quality. Bulgarian Journal of Agricultural Science 4:49-53. 
Jackson, M. (2007) Ethylene-promoted elongation: An adaptation to submergence stress. Annals of Botany 101:229-248.

Jakubiak, M. and Gdowska, K. (2013) Innovative environmental technology applications of laser light stimulation. Energy and Automation 3:14-21.

Jamil, Y., Perveen, R., Ashraf, M., Ali, Q., Iqbal, M. and Ahmad, M. (2013) He-Ne laser-induced changes in germination, thermodynamic parameters, internal energy, enzyme activities and physiological attributes of wheat during germination and early growth. Laser Physics Letters.doi:10:045606-045614.

Jia, Z. and Duan, J. (2013) Protecting effect of He-Ne laser on winter wheat from UV-B radiation damage by analyzing proteomic changes in leaves. Advances in Bioscience and Biotechnology 4:823-829.

Karu, T., Pyatibrat, L. and Kalendo, G. (1995) Irradiation with He-Ne laser increases ATP level in cells cultivated in vitro. Journal of Photochemistry and Photobiology B 27:219-223.

Lin, K., Tsou, C. Hwang, S. Chen, L. and Lo, H. (2006) Paclobutrazol pre-treatment enhanced flooding tolerance of sweet potato. Journal of Plant Physiology 163:750-760.

Maltby, E. (1991) Wetlands their status and role in the biosphere. In: Jackson, M. B., Davies, D.D. and Lambers, H. (eds) Plant Life under Oxygen Deprivation: Ecology, Physiology and Biochemistry. The Hague: SPB Academic, pp. 3-21.

Metwally, S. A., Mohamed, S. L. M., Abou-Leila, B. H., and Aly, M. S. (2014) Effect of drought stress and helium neon (He-Ne) laser rays on growth, oil yield and fatty acids content in caster bean (Ricinus communis L.). Agriculture, Forestry and Fisheries 3:203-208.

Minitab Inc. (2013) Minitab Statistical Software Release 17 for Windows. State College:Pennsylvania.

Mirshekari, B. (2015) Physical seed treatment techniques may influence stand establishment and yield of wheat in delayed cropping. IDESIA 33:49-54.

Mohammadi, S., Shekari, F., Fotovat, F. and Darudi, A. (2012) Effect of laser priming on canola yield and its components under salt stress. International Agrophysics 26:45-51.

Mosneaga, A., Lozovanu, P. and Nedeff, V. (2018) Investigation of biostimulation effects on germination and seedling growth of some crop species. Cellulose Chemistry and Technology 52:551-558.

Muthusamy, A., Kudwa, P. P., Prabhu, V., Mahato, K.K., Sankar Babu, V., Radhakrishna Rao, M., Mantdyat Gopinath, P. and Satyamoorthy, K. (2012) Influence of Helium-Neon laser irradiation on seed germination in vitro and physico-biochemical characters in seedlings of brinjal (Solanum melongena L.) var. Mattu Gulla. Photochemistry and Photobiology 88:1227-1235.

Paparella, S., Araújo, S. Rossi, G. Wijayasinghe, M. Carbonera, D. and Balestrazzi, A. (2015) Seed priming: state of the art and new perspectives. Plant Cell Report 34:1281-1293.

Perata, W., Armstrong, W. and Voesenek, L. A. C. J. (2011) Plants and flooding stress. New Phytologist 190:269-273.

Perveen, R., Jamil, Y. Ashraf, M. Ali, Q. Iqbal, M. and Ahmad, M. R. (2011) He-Ne laser induced improvement in biochemical, physiological, growth and yield characteristics in sunflower (Helianthus annuus L.). Photochemistry and Photobiology 87:1453-1463.

Podlesna, A., Gladyszewska, B., Podleśny, J. and Zgrajka, W. (2015) Changes in the germination process and growth of pea in effect of laser seed irradiation. International Agrophysics 29:485-492.

Podleśny, J. and Podlesna, A. (2004) Morphological changes and yield of selected species of leguminous plants under the influence of seed treatment with laser light. International Agrophysics 18: $253-260$.

Podleśny, J., Stochmal, A., Podleśna, A. and Misiak L. E. (2012) Effect of laser light treatment on some biochemical and physiological processes in seeds and seedlings of white lupine and faba bean. Plant Growth Regulation 67:227-233.

Qiu, Z. B., Liu, X., Tian, X. J. and Yue, M. (2008a) Effects of $\mathrm{CO}_{2}$ laser pretreatment on drought stress resistance in wheat. Journal of Photochemistry and Photobiology B., Biology 90:17-25.

Qiu, Z. B., Liu, X., Tian, X. J. and Yue, M. (2008b) Influence of He-Ne laser irradiation on protective enzyme activities and lipid peroxidation in wheat seedlings by drought stress damage. Journal of Plant Ecology (Chinese Version) 32:1002-1006.

Qiu, Z. B., Li, F. M., Wang, F. and Yue, M. (2008c) Effects of $\mathrm{CO}_{2}$ laser on glutathione-dependent antioxidative system in wheat seedling under drought stress. Journal of Wuhan Botanical Research 26: 402-406.

Qiu, Z. B., Li, J. T. and Yue, M. (2010) The damage repair role of He-Ne laser on wheat exposed to osmotic stress. Canadian Journal of Plant Science 90:691-698.

Qiu, Z., Li, J., Zhang, M., Bi, Z. and Li, Z. (2013) He-Ne laser pretreatment protects wheat seedlings against cadmium induced oxidative stress. Ecotoxicology and Environmental Safety 88:135-141. 
Qiu, Z, Yuan, M., He, Y., Li, Y. and Zhang, L. (2017) Physiological and transcriptome analysis of He-Ne laser pretreated wheat seedlings in response to drought stress. Scientific Reports 7:6108.

Ramírez, R., Gonzalez, L. M., Camejo, Y., Zaldívar, N. and Fernández, Y. (2006) Estudio de radiosensibilidad y selección de rango de dosis estimulantes de rayos $\mathrm{X}$, en cuatro variedades de tomate (Lycopersicom esculentum Mill). Cultivos Tropicales 27:63-67 [In Spanish].

Rasouli, Z., Mohammadi, S. P., Shekari, F. and Khan Mohammadi, S. (2012) Effect of laser priming and salinity stress on canola characteristics using ANN. American-Eurasian Journal of Agricultural and Environmental Sciences 12:1395-1405.

Rimal, B., Ranaivoson, R. M., Czarnecka, K. P. and Dobrowolski, J. W. (2014) Laser biotechnology for enhanced rooting and shooting of Salix viminalis in hydroponic condition for better adaptation in industrially contaminated land. International Journal of Environmental Bioremediation and Biodegradation 2:228-230.

Rodríguez, S., Ortega, E. and Silva, J. (2017) Effect of flooding on stomatal density and stomatal length in six sugarcane genotypes. International Journal of Advanced Research 5:709-718.

Rybinski, W. and Garczynski, S. (2004) Influence of laser light on leaf area and parameters of photosynthetic activity in DH lines of spring barley (Hordeum vulgare L.). International Agrophysics 18:253-260.

Salyaev, R. K., Dudareva, L. V., Lankevich, S. V., Makarenko, S. P., Sumtsova, V. M. and Rudikovskaya, E. G. (2007) Effect of low intensity laser irradiation on the chemical composition and structure of lipids in wheat tissue culture. Doklady Biological Sciences 412:87-88.

Sasidharan, R. and Voesenek. V. (2015) Ethylene mediated acclimations to flooding stress. Plant Physiology 169:3-12.

Szajsner, H. and Bąbelewski, P. (2014) The Influence of laser beam and auxins on rooting of leather leaf viburnum (Viburnum rhytidophyllum Hems1.) cuttings. Journal of Horticultural Research 22:63-66.

Vasilevski, G. (2003) Perspectives of the application of biophysical methods in sustainable agriculture. Bulgarian Journal of Plant Physiology Special Issue:179-186.

Voesenek, L. A. C. J. and Van Der Veen, R. (1994) The role of phytohormones in plant stress: two much or too little water. Acta Botanica Neerlandica 43:91-127.

Voesenek, L. A. C. J., Van der Sman, A. J. M., Harren, F. J. M. and Blom, C. W. P. M. (1992) An amalgamation between hormone physiology and plant ecology: A review on flooding resistance and ethylene. Journal Plant Growth Regulation 11:171-188.

Voesenek, L. A. C. J., Banga, M., Thier, R. H., Mudde, C., Harren, F., Barendse, G. W. M. and Blom, C. W. P. M. (1993) Submergence induced ethylene synthesis, entrapment and growth in two plant species with contrasting flooding resistances. Plant Physiology 103:783-791.

Volin, J. C., Denes, F. S., Young, R. A. and Park, S. M. (2000) Modification of seed germination performance through cold plasma chemistry technology. Crop Science 40:1706-1718.

Wang, X., Huang, M., Zhou, Q., Cai, J., Dai, T., Cao, W. and Jiang, D. (2016) Physiological and proteomic mechanisms of waterlogging priming improves tolerance to waterlogging stress in wheat (Triticum aestivum L.). Environmental and Experimental Botany 132:175-182.

Wu, J., Gao, X. and Zhang, S. (2007) Effect of laser pretreatment on germination and membrane lipid peroxidation of Chinese pine seeds under drought stress. Frontiers of Biology in China 2:314-317.

Yaldagard, M., Mortazavi, S. A. and Tabatabaie, F. (2008) Application of ultrasonic waves as a priming technique for accelerating and enhancing the germination of barley seed: optimization of method by the Taguchi approach. Journal of the Institute Brewing 22:22-27.

Yang, L., Han, R and Sun, Y. (2012) Damage repair effect of He-Ne laser on wheat exposed to enhanced ultraviolet-B radiation. Plant Physiology and Biochemistry 57:218-221.

Ying, C. and Chen, Y. P. (2010) Research trends on the regulating effect of laser pretreatment on plant growth. Chinese Journal of Eco-Agriculture 18:1125-129.

Yiu, J. C., Juang, L. D., Fang, D. Y. T., Wei, L. C. and Wu, S. J. (2009a) Exogenous putrescine reduces flooding-induced oxidative damage by increasing the antioxidant properties of Welsh onion. Scientia Horticulturae 120(3):306-314.

Yiu, J. C., Wei, L. C., Fang, D. Y. T. and Lai, Y. S. (2009b) Waterlogging tolerance of Welsh onion (Allium fistulosum L.) enhanced by exogenous spermidine and spermine. Plant Physiology and Biochemistry 47(8):710-716.

Zare, N., Sadat Noori, S. A., Mortazavian, M. and Mohammad, S. (2014) Effect of laser priming on accumulation of free proline in spring durum wheat (Triticum turgidum L.) under salinity stress. International Transaction Journal of Engineering, Management, and Applied Sciences and Technologies 5:119-130.

Zhang, J. and Han, R. (2009) Study on the nuclease of wheat seedling under He-Ne laser and ultraviolet-B radiation. Chinese Journal of Laser 36:2619-2624. 